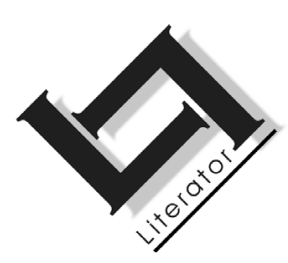

\title{
Dan hecht ik eer geloof aan het verhaal: over enkele narratieve teksten van Martinus Nijhoff
}

\author{
F.R.W. Stolk \\ Departement Nederlands \\ Universiteit Utrecht \\ UTRECHT \\ E-mail: f.r.w.stolk@uu.nl
}

\begin{abstract}
Then, sooner, I give credence to the tale: on some narrative texts by Martinus Nijhoff

With short lyrical poems being the poetical standard nowadays, long story-telling poems can be seen as a provocative genre. Characteristics of modern epic poems can be explored by examining a brief and a story-telling poem by Martinus Nijhoff.

\section{Opsomming}

Dan hecht ik eer geloof aan het verhaal: over enkele narratieve teksten van Martinus Nijhoff

Nu korte, lyrische gedichten de poëtische norm lijken te zijn, vormen lange, epische gedichten een provocerend genre. De karakteristieken van moderne epische gedichten kunnen worden verkend door een kort verhalend gedicht van Martinus Nijhoff onder de loep te nemen.
\end{abstract}

\section{Inleiding}

Lange en verhalende gedichten worden wel ervaren als provocatie. Dat blijkt bijvoorbeeld uit Kevin Walzers polemiek in The ghost of tradition (1998) met academische poëzievorsers in de laatste decaden van de vorige eeuw in Amerika. En hoewel ik het in Nederland niet met zoveel woorden las, denk ik dat de verhalende poëzie ook daar in een kwade reuk staat bij de serieuze poëzielezer. Dit komt onder andere doordat verhalende poëzie geassocieerd kan worden met anekdotische poëzie, een genre dat vooral pejoratief 
genoemd wordt.1 Dat is duidelijk bij beschrijvingen van een generatie van dichters die nauwelijk (meer) meetelt in de Nederlandse poëziegeschiedenis, de Criterium-generatie.

Waarschijnlijk heeft de revolutie van de Vijftigers bijgedragen aan die reputatie. Deze vernieuwers zetten zich - chargerend natuurlijk - af tegen poëzie van dichters als Hoornik, Vasalis, Aafjes en Morriën die verscheen in Criterium en Columbus (De Vriend, 1986:253; zie ook Brems, 2006:104; T'Sjoen, 2005:224). Zo positioneerde Kousbroek zijn nieuwe poëzie door haar af te zetten tegen die van Vasalis: "Dat er niet meer vaag in parken of woestijnen wordt gelopen. Dat de vlucht in de droom aan de dijk wordt gezet, omdat hij onbruikbaar is." (Geciteerd naar Fokkema, 1999:43.) Het uitgangspunt van Criterium was de terugkeer tot het natuurlijke leven, of zoals de sjibboletregel van Vasalis luidt: "eerbied voor de gewone dingen". Dat heeft volgens Middeldorp (1985:55) "geleid tot een stroom van anekdotische poëzie die in de anekdote bleef steken". Die gedichten zouden "er ook de oorzaak van [zijn] dat de poëzie balanceerde op de rand van het drakerige" (Middeldorp, 1985:56).

Hoornik, een van de centrale figuren van Criterium, heeft deze negatieve waardering niet verhinderd. In zijn artikel Criterium voorbij schonk hij in 1958 immers ook aandacht aan "Criterium op-zijnslechtst". Dat openbaarde zich "vooral na zijn opheffing in 1942, toen het anekdotisme in sonnetvorm en de berijmde journalistiek hoogtij gingen vieren" (Hoornik, 1978a:123).

De neerbuigendheid jegens de Criterium-poëzie kan te maken hebben met de vooronderstelling dat poëzie moeilijk moet zijn, althans niet vooral toegankelijk hoeft te zijn, een standpunt dat in ieder geval sinds de Tachtigers in Nederland wordt uitgedragen. Verhalende teksten, en zeker de anekdotische teksten daaronder, hebben juist de reputatie dat ze makkelijk zijn. Dat is af te lezen aan de enorme populariteit door de jaren heen van de poëzie van Vasalis, en ook

1 Esther Jansma's gedichten werden tot de anekdotische poëzie gerekend. Zij zei hierover:

Hier heb je een indeling in hermetisch en anekdotisch. Alle gedichten met een externe gebeurtenis als aanleiding of onderwerp worden daarbij tot de anekdotische poëzie gerekend, tot de 'kleine' poëzie dus. In Amerika rekenen ze in 'lyrical' en 'narrative', een onderscheid dat niet het onderwerp van een gedicht betreft, maar de verteltrant. Die Nederlandse angst voor onderwerpen heeft iets benepens. Als je je met de Nederlandse poëzieopvatting identificeert, belemmer je jezelf als dichter. (Geciteerd naar Loontjens, 2005.) 
van die van Rutger Kopland, een vertegenwoordiger van de latere, aan Criterium gerelateerde Tirade-richting.

De combinatie van poëzie, verhaal(tje) en eenvoud sprak recent in berichtgeving omtrent de benoeming van de "populaire Carol Ann Duffy als eerste vrouw [...] tot Poet Laureate van het Verenigd koninkrijk". De vette kop boven het stuk in de NRC luidt: "Verhalend dichteres van toegankelijke poëzie". In het artikel stelt de verslaggever dat Duffy's werk wordt gekenmerkt door

een verhalende stijl. Haar werk leest volgens de meeste critici makkelijk, maar bezit toch veel diepgang. De combinatie maakt haar tot de best verkopende dichter[e]s van het land. Haar zeven bundels voor volwassenen worden wel compacte romans genoemd. (Van Straaten, 2009.)

Mijn zoektocht in de afgelopen jaren naar moderne lange en verhalende, kortweg epische gedichten heeft me aan het twijfelen gebracht. Zijn er wel moderne epische gedichten? Wat zouden in de moderne tijd epische gedichten zijn? Is het (nog) zinvol om epiek van lyriek te onderscheiden? Zijn alleen lange(re) gedichten eventueel te beschouwen als (moderne) epische gedichten? Zijn anekdotische gedichten ook verhalende gedichten? Zijn zogenoemde gestaltegedichten episch of lyrisch? Is het door onder anderen Van Boven en Dorleijn (1999:23-25) onderscheiden genre van de objectieve lyriek wel een apart genre? Allemaal vragen, opgeroepen door het denken over moderne epische poëzie, die makkelijker te stellen zijn dan te beantwoorden. Daar komt bij dat, zodra men een afbakening overweegt, classificatieproblemen opdoemen die het zicht op de teksten kunnen veranderen, verruimen, verdiepen. Het onderscheiden van epische poëzie lijkt literairhistorisch of algemeen literairwetenschappelijk misschien niet zinvol in een tijd waarin aan een prescriptieve poëtica geen behoefte meer is en genreonderscheidingen vervagen, $\mathbf{2}$ maar het onderscheid kan als heuristisch middel welzeker vruchtbaar, vormend en verrijkend werken. Dat allereerst voor de onderzoeker als lezer, en wellicht ook voor de onderzoeker als classificator: misschien blijken die onderscheidingen niet zo helder als we al eeuwen gewend zijn om te denken dat ze zouden zijn. De werkswinkel over "Die verskyningsvorme en funksies van narratiewe strukture en tegnieke in liriese poësie" (Potchefstroom, 2-

2 Wellicht was Vestdijk de laatste dichter die in de twintigste eeuw in zijn Verzamelde gedichten (1971) onderscheid maakte tussen "Lyrische poëzie" (deel I en II) en "Epische en andere poëzie" (deel III). 
4 juli 2009) was een goede aanleiding om weer eens over verhalende poëzie na te denken.

\section{Waarom nu weer Nijhoff?}

Martinus Nijhoff (1894-1953) is een van de belangrijkste, invloedrijkste, meest gelezen dichters van de Nederlandse moderniteit en moderne tijd, niet alleen vanwege zijn poëzie overigens, maar ook vanwege zijn kritieken en essays over poëzie. Gedichten als "Awater", "Het uur U" en "Het veer", 3 maar ook "Het kind en ik", "Het stenen kindje", "De moeder de vrouw" en "Impasse" weet iedere poëzielezer wel te noemen, of de titel in ieder geval. En natuurlijk "Het lied der dwaze bijen". Regels of fragmenten als "Ik zou een dag uit vissen", "Lees maar, er staat niet wat er staat", "Wij stonden in de keuken, zij en ik" en "lk ging naar Bommel om de brug te zien", "Een geur van hoger honing" kent iedere liefhebber uit het hoofd.

Nijhoffs werk leent zich daarom goed voor reflectie over moderne epische poëzie. In zijn squib Lyrische poëzie, verhalende poëzie, en verhalende lyriek noemt Mooij (1995) lange en korte, lyrische en verhalende gedichten van onder anderen Nijhoff, en stelt dat er voor

Nederlandse letter- en (wie weet) taalkundigen [...] aanleiding te over [is] het verschijnsel van de verhalende lyriek grondig te bestuderen. De vraag naar de rol van het verhaal in de lyriek (zeker ook in de Nederlandse lyriek) is belangwekkend genoeg, en het bijbehorende materiaal inspirerend. (Mooij, 1995:317318.)

Uitgaande van de stelling dat Nijhoff lange, naar het epische neigende gedichten kon schrijven die breed gewaardeerd worden, wil ik verkennen of een van zijn kortere gedichten niet even zo goed als verhalend gedicht gelezen en begrepen kan worden, in plaats van als lyrisch gedicht. En als dat niet het geval is, wat maakt dan het verschil uit?

Een literairhistorische bijkomstigheid is Nijhoffs verwantschap met de Criterium-poëzie. Hoornik (1978b:142) schreef over hem:

Nijhoff, de poëtische ontdekker der werkelijkheid, was de stille, ernstige en voorname gangmaker van een romantisch-realis-

3 De Engelse vertaling van de versregel uit "Het veer" in de titel van mijn bijdrage ontleen ik aan de vertaling van het gedicht door Henriëtte Schuurbeque Boeye (Nijhoff, 1955:544). 
tische poëzie, waarin naar een synthese tussen hemelse en aardse tendensen, tussen waarneming en verbeelding werd gestreefd.

Voorts:

Door Marsman theoretisch aan de orde gesteld, door Nijhoff poëtisch verwezenlijkt, en door de jongeren [...] in hun beste momenten verdiept, is er een zeer gevarieerde, door de werkelijkheid geïnspireerde dichtkunst ontstaan, die kenmerkend is voor een generatie en voor een gemeenschap, in wier onderbewustzijn het mene tekel van de ondergang staat geschreven. (Hoornik, 1978c:100.)

En Cola Debrot, de andere Criterium-voorman, zei dat hij in "Het uur U" van Nijhoff de "vervulling" zag van wat de Criterium-dichters voor ogen stond (Zie Ross, 1986:224).

\section{Afbakening: verhalende teksten - lang-kort, episch- lyrisch}

Bij mijn verkenning van een van Nijhoffs korte verhalende gedichten oriënteer ik me op zes narratieve kenmerken die te destilleren zijn uit diens beroemde lange verhalende gedichten, "Awater", "Het uur U" en "Het veer". In die gedichten treedt een verteller op. (Wie deze formulering te theatraal vindt: er is een verteller of vertellende instantie in aan te wijzen.) Er komen personages in voor. Er is sprake van gebeurtenissen en/of dialogen. Die handelingen spelen zich af in een ruimte/ruimtes, en ze impliceren of vergen een expliciet vermeld tijdsverloop. De lange verhalende gedichten zijn ten slotte lang, ruimschoots langer dan één pagina druks. 4

Maar deze lange gedichten zijn bij lange na niet zo lang als klassieke epen of romans in verzen van duizenden regels, die mede dank zij die omvang meer verhaalstof kunnen beslaan en zo makkelijker die "all-inclusiveness" of thematisch zwaarte kennen die volgens onder anderen Merchant (1979) kenmerkend is voor episch werk door de eeuwen heen. 5 Wie Medousa (1947) van Van Eyck

4 Dit in tegenstelling tot bijvoorbeeld sonnetten, zelfs de extreem uitgebreide sonnetten zoals Achterberg presenteert in zijn Spel van de wilde jacht (1957), een als een lang gedicht te beschouwen bundel van 43 gedichten.

5 De epen worden wellicht steeds korter. De klassieken en neo-klassieken schreven er van tienduizenden versregels; Adam Roberts (1999) stelt voor de Victoriaanse en romantische Engelse epen een ondergrens van duizend regels. 
las, of Bragi (1901) van Schepers, de volledige Mei (1889) van Gorter, of de tweede versie van diens Pan (1916), kan schamper opmerken, net als Harold Bloom deed met betrekking tot John Ashberry's Self-portrait in a convex mirror: "It would not have been thought a long poem by Browning, but five hundred and fifty-two lines is a long poem for our damaged attention-spans these days." (Bloom, 1979:22.) Sinds de komst van het internet en andere digitalia zijn onze "attention-spans" waarschijnlijk ernstiger beschadigd geraakt. Omdat de Nederlandse traditie van lange gedichten anders ál te kort zou worden, reken ik gedichten van minimaal 197 regels al tot de lange gedichten. Dat is precies het aantal versregels van Achterbergs Ballade van de gasfitter (1953), die ik graag in een beschouwing van het genre zou kunnen betrekken.

Met die ballade dient zich meteen een ander probleem aan: is het wel één lang gedicht, of kan het beter gezien worden als een bundel van veertien sonnetten (waarvan er een vijftien regels telt) met een verhalende draad erdoorheen? Afgaande op de titel wordt het in ieder geval gepresenteerd als een gedicht. Daarmee staat ook de deur open naar Perks Mathilde-cyclus (1882), die in zijn oorspronkelijk vorm uit 106 sonnetten bestond die volgens de dichter zelf door de draad van een verhaal met elkaar verbonden waren. 6

De opsomming van narratieve kenmerken van Nijhoffs epiek hierboven komt aardig overeen met de werkdefinitie die Mieke Bal (1990:18) geeft van een verhalende tekst in De theorie van vertellen en verhalen.

[E]en tekst [is] een als eindig, gestructureerd gezien geheel van taaltekens. Een verhalende tekst is een tekst waarin een instantie een verhaal vertelt. Een verhaal is een op een bepaalde wijze gepresenteerde geschiedenis. Een geschiedenis is een serie logisch en chronologisch aan elkaar verbonden gebeurtenissen, die worden veroorzaakt of ondergaan door 'acteurs'. Een gebeurtenis is de overgang van een toestand naar een andere toestand. Acteurs zijn instanties die handelingen verrichten. Ze zijn niet noodzakelijk menselijk. Handelen is een gebeurtenis veroorzaken.

$6 \quad$ Overigens is dat ene vijftienregelige sonnet van Achterberg een vergelijkbaar genreprobleem op microniveau: Is het een sonnet of niet? Als het antwoord daarop luchthartig is: er zijn nu eenmaal ook uitgebreide sonnetten, dan is dat andere probleem ook opgelost: er zijn nu eenmaal epische gedichten die uit losse-maar-verbonden gedichten bestaan. 
Niets in deze werkdefinitie van verhalende teksten verzet zich ertegen om er ook verhalende gedichten mee te beschrijven. Als er al bezwaren zijn, gelden die net zo zeer voor de definiëring van verhalend proza als voor die van poëzie.

Dit is niet vanzelfsprekend, want een andere studie die, net als die van Bal, handelt over gebeurtenissen, tijd, focalisatie en wat al verhalends meer, sluit lyrische poëzie expliciet uit. Rimmon-Kenan (1996:15) beschrijft in Narrative fiction haar object als volgt: "By 'narrative fiction' I mean the narration of a succession of fictional events." En: "An event [...] may be said to be a change from one state of affairs to another". Maar: "The definition [...] suggests how narrative fiction differs from other literary texts, such as lyrical poetry or expository prose. Unlike the latter, narrative fiction represents a succession of events." (Rimmon-Kenan, 1996:2.) Het lijkt erop dat "the latter" mede verwijst naar "lyrical poetry". Dat betekent niet dat Rimmon-Kenans definitie van "narrative fiction" niet deugt, maar wel dat haar concept van lyrische poëzie al te eng is. (De woorden lyric en poetry zijn niet opgenomen in het register van haar boek.)

Een naar mijn idee algemeen acceptabele omschrijving van lyriek geven Erica van Boven en Gillis Dorleijn in Literair mechaniek (1999). Zij tonen zich welbewust van het door Mooij opgemerkte onderscheid tussen lyriek en poëzie. Hun beschrijving van lyriek gaat inderdaad het conflict aan met de hierboven gegeven definities van "narrative fiction" en verhaal.

Lyrische teksten worden gekenmerkt door een monologische taalsituatie. $\mathrm{Er}$ is een woordvoerder: een ik dat zich uit. Vaak spreekt die woordvoerder een jij of gij toe. Maar die jij of gij zegt niets terug. We krijgen alleen de monoloog van het ik te horen. De woordvoerder geeft uiting aan een momentane ervaring. Er wordt dus geen geschiedenis gepresenteerd, dat wil zeggen[:] de sprekende persoon vertelt niet over een reeks gebeurtenissen. (Van Boven \& Dorleijn, 1999:15.)

In verband met die toe- of aanspreking hanteren zij de term apostrofe (Van Boven \& Dorleijn, 1999:16), die impliciet is ontleend aan Culler (1983). Verder geven Van Boven en Dorleijn aan dat de toegesprokene niet een (bestaand) persoon hoeft te zijn. (Vergelijk hierboven de kanttekening van Bal bij de acteurs in een verhaal. ${ }^{7}$

$7 \quad$ Een heldere beschrijving van lyrische poezie geeft ook Majorie Perloff in The dance of the intellect (1996), in een bespreking van "Snowstorm in the MidWest" van James Wright; vooral dit vind ik een mooie formulering: "[T]he 'l' of 
Dat aanspreken stelt de/het aangesprokene aanwezig door middel van de taal, waarmee de aanspreekhandeling een magisch of bezwerend karakter krijgt (Van Boven \& Dorleijn, 1999:17). Dit strookt met wat Culler noteert met betrekking tot apostroferende poëzie: "Nothing need happen because the poem itself is to be the happening." (Culler, 1983:149.)

Deze benaderende afbakening van lyriek komt in principe sterk overeen met de demarkering van (sommige vormen van) poëzie door Brems in De dichter is een koe (1991). Hij refereert aan poëzie die in wezen een definitie is: "De dichter vertaalt het bekende in het onbekende, hij gebruikt de vorm van de definitie om zijn eigen gang te gaan. [...] Het heet dat dichters het wezen van de dingen onthullen." (Brems, 1991:13.) En:

De dichter zoekt woorden om vat te krijgen op wat hem overweldigt. Ik geloof dat dat de bron is van alle poëzie: de wil om klaarheid te scheppen in de wereld. [...] Om op dat onbekende vat te krijgen is er maar één middel, het inschakelen van iets wat wel bekend is, volgens de formule $a=b$. Dat doet het woordenboek met zijn begrippen, dat doet de wetenschap met haar modellen, dat doet de criticus met zijn jargon en zijn stromingen. De dichter doet dat langs een omweg. [...] Heel in de diepte is alle poëzie een poging tot definitie. (Brems, 1991:15-16.)

In de context van narratieve structuren in lyrische poëzie voeg ik eraan toe: definities zijn momentane begripspogingen. 8 Of, toch in Brems' (1991:16) eigen woorden: "[H]et gedicht is de definitie van een begrip waarvoor geen ander woord bestaat dan die definitie zelf: het gedicht is een neologisme."

Lyriek wordt verder gekenmerkt door, wordt zelfs gekenmerkt als (emotionele) exclamatio, waarbij het object daarvan kan samenvallen met dat van de apostrofe. Verder rekenen Van Boven en Dorleijn als gezegd ook de zogenoemde "objectieve lyriek" tot de lyriek. Het gaat dan om teksten (ze schrijven: "gedichten") waarin een observerend ik, dat soms niet tekstueel wordt uitgedrukt, niet aan- en

the poem is concerned to utter rather than to address." (Perloff, 1996:156; cursivering - FRWS.)

8 Vergelijk ook wat Perloff (1996:156) noteert over de "ik" in lyrische poëzie: "[H]is back turned to the audience in a state of rapt self-communion, his speech takes the form of a series of short, gnomic, declarative sentences in the present tense." 
uitroept, maar registreert en constateert. In een gedicht als Gorters "De stille weg" (in de bundel Verzen, 1890) "is het lyrisch moment als het ware [...] verhuld aanwezig" (Van Boven \& Dorleijn, 1999:23). En "het lyrisch moment" refereert dan aan de eigenschap van lyriek, dat het ik daarin geen verhaal vertelt of verslag aflegt, "maar [...] uitdrukking [geeft] aan wat hij nu ervaart en die ervaring kent geen duur, maar is momentaan" (Van Boven \& Dorleijn, 1999:16). In (dit soort) lyriek treedt dus geen extradiëgetische verteller op (zie Rimmon-Kenan, 1996:91-92).

Een fundamenteel onderscheid tussen lyrische en andere gedichten is dus de aanwezigheid van een geschiedenis. Naar aanleiding van een gedicht van Toon Tellegen zeggen Van Boven en Dorleijn (1999:26) stellig: "Dit gedicht bevat een geschiedenis en hoort daardoor niet tot de lyriek. Maar het is wel poëzie. [...] Zodra het mogelijk is een geschiedenis te construeren [...] is een tekst (ook) een verhaal." Ze zijn hier niet volledig en zetten daardoor aan tot nadere verkenning van een door hen vooralsnog non-existent verklaard genre: de verhalende lyrische poëzie. Het postulaat van objectieve lyriek (lyriek met een verhuld lyrisch moment) kan de deur openzetten naar subjectieve epiek, oftewel: lyriek met een geëxpliciteerde en geïntegreerde vertelling over de aanleiding tot het lyrisch moment. Lyriek zou immers geen gebeurtenissen vertellen, maar de uiting zijn van een momentane ervaring. Die ervaring kan evenwel heel goed de reactie zijn op een verandering die is opgetreden in de (persoonlijke) toestand van het lyrisch ik. Zoals een ik in een lyrische tekst kan uitbarsten bij het (al dan niet gefingeerd) zien van een Griekse urn, kan hij/zij dat ook bij het besef van bijvoorbeeld het vertrek van een geliefde, en die laatste situatie is nauwelijks voorstelbaar zonder de (geïmpliceerde) voorgeschiedenis van eenzaamheid, ontmoeting en verbintenis. Een verkenning van gedichten van Nijhoff kan dienen als aanzet tot een schets van dit genre en tot een verkenning van de verhalende aspecten en technieken van lyrische poëzie.

\section{Drie lange verhalende gedichten van Nijhoff}

In elk van de drie genoemde epische gedichten van Nijhoff is een instantie aan te wijzen die een verhaal vertelt over de faits et gestes van een of meer (andere) personages. Dat alleen lijkt me al reden genoeg om ze verhalend te noemen. Ze bevatten elk ook een omslag in de vertelsituatie. In "Awater" verdwijnt de expliciete ik-verteller in de overgang naar de laatste laisse, terwijl in de andere twee gedichten de aanvankelijk verborgen verteller zich vooral aan het 
slot met enkele persoonlijke (metafictionele) overwegingen onverwacht juist op de voorgrond van de vertelling dringt en zich als het ware van zijn lyrische kant laat zien.

Afgaande op die wending wordt de karakterisering begrijpelijk die Hoornik gaf van deze gedichten. Hij (Hoornik, 1978b:147) noemt ze een "epo-lyrisch mengsel".

De muze van Nijhoff is niet slechts een lyrische, maar ook een verhalende, en zoals de dichter tussen realiteit en romantiek de synthese vond, zo vindt hij haar ook tussen de twee vormen van dichtkunst die hij in de grote gedichten 'Awater' en 'Het uur $U$ ' tot een epo-lyrisch mengsel verbindt, waarin hij bovendien enige proefjes van dramatiek ten beste geeft.

In alledrie de gedichten kan een minstens één van de personages aangewezen worden als de held, de centrale figuur door wie er veranderingen optreden, of die veranderingen ondergaat. Deze helden zijn Awater (en ook de ik-figuur), respectievelijk een man (maar ook de straatbewoners), en Sebastiaan (maar misschien ook de ik-verteller).

Het verhaalde gebeuren speelt zich af in een (destijds) herkenbare, "actuele" ruimte, die niet, of niet alleen, of niet in de eerste plaats de afspiegeling is van de gemoedstoestand van een lyrisch subject. Aan het eind van het vertelde is er een verandering opgetreden die tijd heeft gevergd. De ik-figuur en Awater gaan weer uit elkaar na een tijdje samen te hebben opgetrokken (althans in de optiek van de ik-figuur); de mensen in de straat zijn geestelijk wakkergeschud in de tijd die het de man kost om de straat door te lopen; Sebastiaan is tot een diep inzicht gekomen, en de verteller niet minder.

Wat betreft de dialogen stellen de verhalende gedichten van Nijhoff niet veel voor. Ze komen in "Awater" nauwelijks voor, en opmerkelijk genoeg helemaal niet tussen de twee hoofdfiguren, de ik-figuur en Awater. En ook wat betreft de directe interactie tussen de twee hoofdfiguren is het gedicht "Awater" nogal mager. De ik-figuur onderneemt van alles, maar vooral zo, dat Awater er niets van merkt. Hij negeert hem volkomen. 9

9 Voorbeelden: "zo snelt hij langs me, en ik voel mij doorboord"; "De stad verleent de voet geluidloosheid"; "ik was hem bijna kwijt"; "Hij kijkt mijn kant uit, zodat ik vermoed / dat hij mij roept als hij de kelner roept"; "Ik zorg - want het is stil en de straat nauw - gelijke tred met Awater te houden. / Zo hoort hij niet dat iemand hem bijhoudt." En wanneer op het laatst er bijna een ontmoeting 
Ook Sebastiaan handelt wel, maar van interactie is geen sprake: hij ziet en reflecteert. Hij maakt zich uit zijn boeien los, ziet rond, klimt een pad op en verwijlt een uur of wat, geleund tegen een muur. Hij ziet volk bij de pont en de pont heen en weer gaan. Hij is bevreemd en kijkt het dijkhuis binnen en is bevreemd en gekweld doordat hij nu ziet dat hij iets heeft nagelaten.

In "Het uur U" is de interactie eveneens miniem: de man loopt de straat door; de bewoners, achter hun ramen, reageren wel op zijn passage, maar blijven daarbij in zichzelf gekeerd; de kinderen op de stoep interacteren niet sterker dan de ik-figuur met Awater in het gedicht "Awater": schaduwlopen. Zij praten niet met de man, alleen onderling.

Het ontbreken van interactie in woord en handeling tussen de hoofdfiguren draagt er wellicht toe bij dat alle vertel- en lezersaandacht uitgaat naar de overwegingen van personages op dat moment, in het bijzonder die van de ik-figuur, van Sebastiaan, respectievelijk van de straatbewoners, alsook naar de overwegingen van alledrie de vertellers. Dat is als het ware hun lyrisch moment, hun moment van inzicht waarop ze denken: zó zit het.

\section{Een kort verhalend gedicht van Nijhoff}

Zoals gezegd is Nijhoff niet alleen bekend door deze lange, verhalende gedichten, maar ook door zijn kortere gedichten, waaronder sonnetten, bijvoorbeeld de sonnetten die een aparte afdeling vormen in Nieuwe gedichten (1934). Het sonnet lijkt me bij uitstek een lyrische dichtvorm, zeker sedert de Tachtigers zich erover ontfermd hebben en het hebben uitgebuit als schier uniek medium voor het overbrengen van de gevoelsnuances van de dichterlijke ziel.10 Maar het sonnet is meer dan dat. Dat blijkt bijvoorbeeld uit Verweys Van het leven, een gedicht in sonnetten (1889), Achterbergs Ballade

plaatsvindt, groet Awater de ik uiteindelijk nadrukkelijk niet: "Awater [...] / kijkt naar mij om als kent hij mij van ouds. / Maar waar? in een tram? in een schouwburgpauze? / zo vraagt de blik waarmee hij mij beschouwt, / terwijl hij want het waait - zijn hoed vasthoudt." Bijna had hij groetend de hoed gelicht (denkt de ik-figuur).

10 "Het sonnet [...] vat [...] iedere flikkering en tint van het menschelijk gemoed," zei Kloos (2003:38). En: "ledere aandoening is als een golf der ziel. [...] Niet anders [is] de rhythmische golf van het sonnet." (Kloos, 2003:38-39.) Verwey (1885-1886:67) zei over deze materie: "Het sonnet is een lyrische dichtvorm. De lyrische kunst is de kunst der aandoeningen; het lierdicht in zijn eenvoudigste gedaante is éen enkele stemming die in woorden is uitgedrukt." 
van de gasfitter (1953) en Spel van de wilde jacht (1957). Ook in Nijhoffs sonnetten zijn narratieve technieken aan te wijzen. Een openingsregel als deze is in dat opzicht onmiskenbaar:

Wij stonden in de keuken, zij en ik.

Hier worden door een ik-verteller twee personages geïntroduceerd, een vrouw en de vertellende ik zelf in zijn (vroegere) hoedanigheid van belevende ik.11 De personages worden in medias res in een tijd neergezet, die een vervolg van handelingen impliceert; het gedicht zal niet gaan over hoe ze daar hun staan stonden te beleven. Ze worden ook in een duidelijk gemarkeerde ruimte neergezet: de, of hun keuken. 12

In de volgende regel wordt, zoals wel past bij een dergelijk verhaalbegin, de achtergrond van de actuele verhaalsituatie alsnog uit de doeken gedaan. ${ }^{13}$ Bovendien wordt de ik-figuur sprekend/denkend ingevoerd en wordt een spanningsboog opgezet doordat er een voornemen tot handeling wordt geuit: hij wil iets gaan zeggen. (Terzijde: inmiddels zijn de eerste vijf kenmerken van de lange verhalende gedichten uit de paragraaf over de afbakening hier aan bod gekomen.) Tegelijk wordt er wezenlijke informatie achtergehouden. Dat is te relateren aan het feit dat er een ik-personage aan het woord is die, zoals wel vaker met personages het geval is, door de lezer niet in één oogopslag volkomen gekend wordt, maar wiens doen en laten en denken langzaam, en niet noodzakelijk volledig, duidelijk worden:

Ik dacht al dagen lang: vraag het vandaag.

De tijd wordt uitgerold, zowel naar het verleden als naar de toekomst. Daarmee wordt duidelijk dat het personage met een probleem zit en naar een oplossing streeft. En daarmee hebben we een

11 Uitgaande van de meest gebruikelijke vertelvormen, is de ik-verteller qua sexe hoogstwaarschijnlijk vergelijkbaar met die van de auteur.

12 Dat de keuken niet echt een hot spot is in de Nederlandse (lyrische) poëzie, is opmerkelijk (zie Lucas, 1993). Zo'n eenvoudige, alledaagse ruimte lijkt typerend voor een eenvoudige anekdote.

13 Wat betreft "Het uur U" zijn twee interpretaties mogelijk. De voorgeschiedenis wordt niet verteld, of doordat de straatbewoners door het verschijnen van de man aan het denken worden gezet over hun ontwikkeling tot nu toe, komt de voorgeschiedenis zo toch aan bod. Alleen de man die door de straat loopt, blijft zonder. 
narratieve kern te pakken. De psychische eigenschappen van de ikfiguur worden in de daarop volgende regels iets duidelijker, het personagebeeld wordt ontrold:14

Maar omdat ik mij schaamde voor mijn vraag wachtte ik het onbewaakte ogenblik.

De eerder gesignaleerde spanning, het uitstel van handeling, wordt gaande gehouden. Er volgt alleen informatie over de psyche van de ik-figuur. Dit is verhaalanalytisch te beschrijven als een schoolvoorbeeld van één van de drie zogenoemde epische tijden, Deckung: Terwijl de vertelde tijd voortschrijdt, maar er geen handelingen plaatsvinden waarover verteld kan worden, wordt de verteltijd gevuld met het beschrijven van het innerlijk van de ik-figuur. Dit wordt voortgezet in een beschrijving van de al eerder begonnen, maar impliciet gelaten handelingen van de zij-figuur, c.q. het kijken van de ik-figuur:

Maar nu, haar bezig ziend in haar bedrijf, en de kans hebbend die ik hebben wou dat zij onvoorbereid antwoorden zou,

En dan pas komt eindelijk de actie op gang. Dat uitstel speelt in de vertelde geschiedenis, want "al dagen lang" denkt de ik-figuur en handelt hij niet. Aldus is het uitstel als verhaalmotief verwerkt in deze korte tekst. Dit inhoudelijke motief wordt formeel ondersteund door de alliteratie en assonantie. Het uitstel wordt tevens gethematiseerd in de vertelling: het duurt, voor wie de woorden van het gedicht leest, een aantal regels voordat de volgende handeling plaatsvindt. In korte, schriftelijke gedichten is een dergelijke vertelstructuur gemakkelijk te tonen. Het uitstel in de eerste acht regels van "Impasse" kan zo samengevat worden:

Wij stonden [...].

Ik dacht al dagen lang: vraag [...].

Maar omdat ik [...]

wachtte ik [...]

Maar nu, $[\ldots]$ ziend $[\ldots]$,

en $[\ldots]$ hebbend $[\ldots]$

$[\ldots]$,

vroeg ik: [vraag]?

14 Terminologie van Van Boven en Dorleijn (1999:297). Bal (1990:98) spreekt van de accumulatie van kenmerken. 
Dan pas verneemt de lezer wat de ik-figuur dwarszit: "[W]aarover wil je dat ik schrijf?" Een writers block, maar ook meer dan dat. Was het alleen een creatieve impasse, dan had de vraag prozaïscher kunnen zijn: "Zeg, weet jij niet iets waarover ik zou kunnen schrijven?" Maar dat vraagt hij niet. Hij vraagt wat zij wil dat zijn onderwerp zal zijn. Hij maakt zich afhankelijk van haar, onderwerpt zich.

Overigens moet worden opgemerkt dat de ik-figuur geen open kaart speelt. Eerst zegt hij dat hij zich schaamt voor zijn vraag en daarom zo lang wacht; pas daarna zegt hij dat hij op het moment wacht waarop de ander onvoorbereid zou moeten antwoorden; hij geeft niet aan waar deze onverhoedsheid toe dient.

Als deze aap eindelijk uit de mouw is, schiet het nog steeds niet op met de handeling, die slechts een gedachten- en woordenuitwisseling is. Dit blijkt wanneer het vervolg in de handelingssamenvatting wordt opgenomen:

$$
\begin{aligned}
& \text { Juist }[\ldots] \text {, } \\
& {[\ldots]} \\
& {[\ldots] .15}
\end{aligned}
$$

Dan antwoordt zij, [...]

$[\ldots]$

$[\ldots]$ : [antwoord].

Bij dit alles speelt mee dat het de poëzielezer onmiddellijk duidelijk is dat dit een sonnet is, een gedicht waarvan niet alleen de regels zijn geknot door de gebonden vorm, maar ook de strofen, en waarvan de eerste twee strofen traditioneel tegenover de laatste twee staan.16 De lezer ziet in een oogopslag de (mogelijke) inhoudelijke onderdelen van de tekst. Dat heeft poëzie voor op proza. De vorm van de woorden en de plaats van de woorden op de pagina dragen in gedichten bij aan de betekenis.

In extremo is dat in dit gedicht het geval in de eerste regel, die tevens de eerste zin is. Het eerste woord is typografisch per se al gemarkeerd, en wordt dit eens te meer doordat het herhaald wordt in de slotwoorden: "zij en ik" is een niet al te informatieve, bijna

15 In de derde strofe treedt een onverwachte figuur op: de ketel begint als een intrigant dwars door de net gestarte dialoog te fluiten en verandert daarmee de situatie, om met Bal te spreken.

16 Terecht merkt Scholtz (1984:112) na een ongeveer gelijkluidende analyse van dit gedicht op: "Nijhoff gebruik nie om dowe neute die sonnetvorm nie." 
redundante recapitulatie van "Wij", maar staat wel op eindrijmpositie. Daar kan bijgevoegd worden dat de overige informatie van deze opening evenmin indrukwekkend van vertelkracht is. De actie is "stonden"; de locatie is "de keuken". In alles ontkent deze opening de doorgaans voor poëzie kenmerkende concentratie.17

De ontleding van "Wij" in "zij en ik" betekent voor wie gewend is poëzie te lezen dit "wij" is geen "wij" meer, deze eenheid van twee mensen valt uiteen; anders had de dichter dat niet zo genoteerd. Evenzo betekent dat onnozele "stonden", gelet op de titel waaronder het staat, en gelezen op de wijze van de poëzie, dus rekening houdend met wat Jakobson (1977:103-105) de poëtische functie van de taal noemt, inderdaad dat er niet gegáán wordt, dat de gang eruit is, dat de personages stilstaan, vastzitten, klem zijn geraakt. Bij nader inzien is de schijnbaar futloze mededeling zeer betekenisrijk. Juist die tweede, door het specifieke taalgebruik gegenereerde instantie, is mijns inziens kenmerkend voor (het vertellen in) poëzie.

Juist vangt de fluitketel te fluiten aan,

haar hullend in een wolk die opwaarts schiet

naar de glycine door het tuimelraam.

Dan antwoordt zij, terwijl zij langzaamaan

druppelend water op de koffie giet

en zich de geur verbreidt: ik weet het niet.

Deze slotwoorden krijgen hun betekenis doordat ze zowel voor de ik-figuur als voor de lezer het antwoord zijn waar zo lang op gewacht moest worden, en doordat ze het gedicht afsluiten, en doordat ze het gedicht terugsturen naar de titel. Van meet af aan was eigenlijk al duidelijk dat er geen uitkomst is. Aldus verwoordt en definieert dit gedicht de toestand van de ik-figuur. Hoewel ze gesproken worden door een ander personage, zijn de slotwoorden (en is ook het hele gedicht) eigenlijk de verwoording van het lyrisch moment van de ikfiguur. ${ }^{18}$

18 Dit vertellen naar het lyrisch moment toe is ook te zien in "De moeder de vrouw" (Nijhoff, 1990:220). En misschien is zo'n vertelling met een lyrische clou ook te zien in drie lange gedichten van Nijhoff die hiervoor al even ter sprake kwamen. In al de gedichten, behalve in sommige clausen van "Awater", wordt de tekst van personages niet tussen aanhalingstekens gezet, en dus typografisch niet onderscheiden van de vertellerstekst. 


\section{Afbakening door context}

"Impasse" lijkt me een voorbeeld van subjectieve epiek. In dit gedicht staat het verhaal in dienst van het beschrijven, het uitbeelden van het lyrisch moment van de ik-verteller. De interpretatieve keuze om het lyrische het belangrijkst te noemen, is wellicht minder afhankelijk van de gehanteerde poëtische en narratieve technieken, dan van de context waarin het gedicht gepresenteerd en gerecipieerd wordt.

In een afwijkende versie en onder een andere titel is "Impasse" namelijk ook bekend in een andere contex. Het is in eerste en in derde instantie door Nijhoff gepresenteerd als (relatief) geïsoleerd gedicht. In 1935 verscheen het in de almanak Kristal als zelfstandig gedicht, en in 1946 nam Nijhoff het op in de vijfde druk van Nieuwe gedichten, in de afdeling "Acht sonnetten".19 Door de bundeling kreeg het gedicht niet een pregnante, betekenissturende context. Bundeltitel en afdelingstitel bieden de lezer immers weinig houvast. Nijhoffspecialist Wiljan van den Akker (1989:6) noteert hierover: "De vraag naar de samenhang en de eventuele ontwikkeling in de gedichten van de tweede afdeling is nog steeds niet bevredigend beantwoord." Gedichten als "De nieuwe sterren" en "Ad infinitum" noemt hij "nogal cryptisch [...], om niet te zeggen hermetisch [...]" (Van den Akker, 1989:7). En voor wat de afdeling betreft, komt hij niet veel verder dan dat het om conflicten gaat, wat wel aansluit bij de tweeledige sonnetstructuur en bij de thematiek van de bundel, die gerelateerd is aan poëticale en levensbeschouwelijke vernieuwing in Nijhoffs oeuvre en ten opzichte van zijn tijdgenoten.

Tussendoor nam Nijhoff het gedicht, in licht gewijzigde vorm, op in een sonnettencyclus met de overkoepelende titel "Voor dag en dauw", gepubliceerd in De gids (1936). De cyclus wordt voorafgegaan door een brief aan Johan Huizinga, en vormt daarmee een "geheel" volgens de dichter. $20 \mathrm{Hij}$ heeft de cyclus geschreven in reactie op de titel van Huizinga's studie In de schaduwen van morgen (1935), waarin deze de ziekte van het geestelijk lijden van zijn tijd analyseert.

19 Voor de ontstaansgeschiedenis, varianten en context verwijs ik naar de historisch-kritische Nijhoff-editie (Nijhoff 1993, 1:336-344; 2:232-238; 3:414430).

20 Zie Nijhoffs brief aan Colenbrander d.d. 6 september 1936 (Nijhoff, 1993, 2:235). 
Van den Akker (1994:127) zegt dat de cyclus "geen epische structuur" kent die de acht sonnetten tot een geheel samenbindt. Ik neem aan dat hij daarmee bedoelt dat er geen personages zijn, geen handelingen (bijvoorbeeld reizen van de ene locatie naar de andere) of dialogen die over de grenzen van de gedichten doorlopen. De vertellingen in alle acht de gedichten staan wat dat betreft los van elkaar.

Het is meer een web van motieven waarin de gedichten hangen, vastgehouden door dezelfde uitgangssituatie in de tijd, het moment tussen slaap en wake. Binnen dat web is er eenheid geschapen door een contrapuntisch principe: het ene gedicht fungeert als tegenstem voor een ander en ook binnen de afzonderlijke sonnetten wisselen stem en tegenstem elkaar af. De wijze waarop de personages worden getekend zorgt eveneens voor eenheid: acht keer krijgen we uiterst realistische situaties geschetst waarin zich personen bevinden die tegelijk concreet en abstract zijn. (Van den Akker, 1994:127.)

Van groot en interpretatiesturend belang lijkt me dat Nijhoff in de begeleidende brief de strekking van zijn gedichten toelicht:

Ik heb acht menselijke omtrekken getracht te schetsen, zoals zij zich in de morgenschemering gedragen. De ingenieur slapend in zijn woning tegenover de fabriek, het meisje dat zich het haar kamt, de trambestuurder op zijn eerste rondrit door de stad, de twee jonge echtgenoten in hun slaapkamer, de dichter die zich een café voor de geest roept waar hij de vorige avond geweest is, de werkvrouw die een huis begint op te ruimen, de jongen die in het vroege morgenuur huiswerk gaat maken, en tenslotte de twee oudere echtgenoten, die op andere basis, gelijk dat heet, beginnen. (Nijhoff, 1990:255-256.)

De dichter presenteert zijn gedichten als een eenvoudige, nevengeschikkende montage van acht korte vertellingen, die narratief bezien alleen gemeen hebben dat ze zich afspelen voor dag en dauw. Die situering in de tijd suggereert de mogelijkheid tot verdere handeling in de loop van de nieuwe dag, maar die is niet in de vertelling opgenomen. Het slotgedicht is net zo'n vertelling binnen de genummerde reeks. Het gedicht heet niet meer "Impasse", maar "VIII", en is in deze context het sluitstuk van een reeks over mensen, die alle een houding in het leven vertegenwoordigen.21

21 Scholtz (1984:115) merkt op: "Die nuwe 'Impasse', nou naamloos maar genommer, is [...] grondig geïntegreer met die ander sonnette in die reeks." Deze 
Gedicht "VIII" is in de cyclus "Voor dag en dauw" een ik-vertelling door een personage; het is een verhalend gedicht, geen lyriek. De vertelling is gereduceerd tot de monoloog van een van de personages (zoals ook Emants' roman Een nagelaten bekentenis een vertellende monoloog is). In de andere gedichten is makkelijker een auctoriale vertelinstantie of extradiëgetische verteller aan te wijzen.22 Zoals Nijhoff in de lange verhalende gedichten speelt met het vertelperspectief, zo doet hij dat ook in deze verhalende cyclus. ${ }^{23}$

Anderzijds kan met betrekking tot de acht sonnetten in Nieuwe gedichten het volgende worden opgemerkt: "Aan een graf" is een ikvertelling die een apostrofe bevat; "Florentijns jongensportret" is deels objectieve lyriek, deels apostrofe; "Haar laatste brief" is een ik-vertelling; in "De nieuwe sterren" wordt de eerste persoon meervoud gebruikt; "De vogels" is een ik-vertelling, net als "Ad infinitum" en "De moeder de vrouw". Op het laatste na staan alle gedichten geheel of goeddeels in de onvoltooid tegenwoordige tijd. De afdeling heeft dus nogal wat lyrische trekjes. In die context wordt het aannemelijker ook "Impasse" vooral als lyriek te zien.

Een tekstueel en contextueel verschil tussen "Impasse" en "VIII" is de titel. De nummering maakt het gedicht tot één van een groep onder een gezamenlijke titel. "Impasse" is daarentegen door zijn titel (en wegens de weinig zeggende afdelingstitel) veeleer te lezen als een los staand gedicht.

Een tweede tekstueel verschil is het antwoord van de vrouw. Dat luidt in "VIII": "een nieuw bruiloftslied". Daarmee breekt zij de benarde situatie van de ik-figuur open. Ze biedt hem zowel een literair onderwerp om over te schrijven als ook een reëel, moreel onderwerp om over na te denken en om in de toekomst naar te leven.

nieuwe versie is zijns inziens (Scholtz, 1984:116) minder intrigerend als de zelfstandig gedicht: "Nijhoff het [...] 'n groot gedig boeiend gevulgariseer tot iets veel minders as die oorspronklike 'Impasse'. Geen wonder dat die titel 'Impasse' nie meer nodig was nie."

22 Het is eenvoudig om een narratieve kernstructuur in de overige gedichten aan te wijzen. In gedicht I bijvoorbeeld: "De ingenieur [...] droomt, hij laat zijn huis / later, vlak tegen de fabriek aan bouwen." II: "Terwijl [...] vertelt het meisje haar / kleine verhaaltjes" (Nijhoff, 1990:257-263), enzovoort. Een luie lezer zou bij "VIII" kunnen verwachten: Zij stonden in de keuken, zij en hij.

23 Kenmerkend voor de relatieve veronachtzaming van het vertellen in poëzie, en vooral in korte gedichten, is dat Van den Akker (1989:8) wel met betrekking tot "Awater" wijst op het belang van de vertelsituatie, maar niet met betrekking tot de andere nieuwe gedichten. 
"Impasse", daarentegen, is in zichzelf besloten; het einde is een terugkeer naar het begin. Het gedicht "VIII" beschrijft niet alleen een momentane toestand van de ik maar gaat over het verleden, het heden en de toekomst van de twee mensen in de keuken: zij kunnen in de optiek van de vrouw opnieuw een eenheid worden. Juist aan het einde van een overzichtelijke cyclus onder de titel "Voor dag en dauw" lijkt me dat een betekenisrijk antwoord.

\section{Besluit}

Op de woorden komt het aan in poëzie. Met betrekking tot "Het uur U" zegt Sötemann (1991:12-13):

De verdiensten van een vers, ook die van een episch gedicht, liggen [...] niet in de eerste plaats in de intrige, het navertelbare verhaaltje, ook al is dit niet zonder belang en brengt het natuurlijk een levensvisie tot uitdrukking.

De verdiensten van veel goede gedichten liggen in het specifieke, geconcentreerde en betekenisrijke taalgebruik. In een wat hedendaagser taal gevat, klinkt deze stelling aldus:

Nou, onsamenhangend vormvast gelul

lijkt mij ambachtelijke flauwekul ...

In de poëzie draait het juist om de taal.

Volgens mij misbruik jij de poëzie

voor het vertellen van een dom verhaal ...

en kom op zeg, sonnetten ... eigenlijk zie

ik niet goed in waarom je zou gaan zwoegen

op een gedicht dat niks toe kan voegen

aan de reeds bestaande realiteit.

[...] (Wevers, 2009:130-131.)

Deze woorden worden uitgesproken door een personage in de 272 pagina's dikke roman in verzen Bittergarnituur van Arthur Wevers. Paradoxaal genoeg trekt de auteur van deze roman zich weinig tot niets aan van de taal. Veel meer dan wat "onsamenhangend vormvast gelul" brengt hij niet te berde voor wie deze tekst als poëzie probeert te lezen. Om het minder onvriendelijk te zeggen: Zoals wel vaker in verhalend proza, gaat de meeste aandacht uit naar de (in dit geval vooral erotische) verwikkelingen, het verhaaltje; de gebeurtenissen vormen de thematische betekenis van de roman. In ware poëzie daarentegen - zoals die van Nijhoff - tilt de dichter juist door zijn weloverwogen taalgebruik een schijnbaar eenvoudig verhaaltje, een anekdote uit de banaliteit omhoog en verheft het tot een vertel- 
ling met een zeggingskracht die veel verder reikt dan wat er letterlijk aan handelingen vermeld staat.

Anders gezegd: Ook in korte dichtvormen, die hoofdzakelijk voor lyrische uitingen worden gebruikt, zoals het sonnet, zijn narratieve structuren te ontdekken die bijdragen aan de betekenis. Het voorkomen van die verhaalelementen impliceert niet dat zo'n tekst dan ook in wezen episch is. Nijhoffs "Impasse" is kort, verhalend en lyrisch. Anderzijds kunnen ook lange, verhalende gedichten uiteindelijk gericht zijn op de uitbeelding of verwoording van een lyrisch moment. En verder is in de bovenstaande verkenning gebleken dat niet alleen tekst- en vertoogkenmerken meespelen bij het bepalen van het onderscheid tussen epische en lyrische gedichten. Ook de context waarin gedichten gepresenteerd worden, kan daarbij indicatief zijn, zoals blijkt in het geval van "Impasse" en Nieuwe gedichten en sonnet "VIII" in "Voor dag en dauw" van Nijhoff.

\section{Geraadpleegde bronnen}

BAL, M. 1990. De theorie van vertellen en verhalen: inleiding in de narratologie. 5e. herz. dr. Muiderberg: Coutinho.

BLOOM, H. 1979. The breaking of form. (In Bloom, H., De Man, P., Derrida, J., Hartman, G.H. \& Miller, J.H., eds. Deconstruction and criticism. London: Routledge \& Kegan Paul. p. 1-37.)

BREMS, H. 1991. De dichter is een koe: over poëzie. Amsterdam: De Arbeiderspers.

BREMS, H. 2006. Altijd weer vogels die nesten beginnen: geschiedenis van de Nederlandse literatuur 1945-2005. Amsterdam: Bakker.

CULLER, J. 1983. Apostophe. (In Culler, J. The pursuit of signs: semiotics, literature, deconstruction. London: Routledge \& Kegan Paul. p. 135-154.)

DE VRIEND, G. 1986. De poëzie van vijftig. (In Van Bork, G.J. \& Laan, N., reds. Twee eeuwen literatuurgeschiedenis: poëticale opvattingen in de Nederlandse literatuur. Groningen: Wolters-Noordhoff. p. 253-262.)

FOKKEMA, R.L.K. 1999. Aan de mond van al die rivieren: een geschiedenis van de Nederlandse poëzie sinds 1945. Amsterdam: De Arbeiderspers.

HOORNIK, E. 1978a. Criterium voorbij. (In Hoornik, E. Kritisch proza: verzameld werk van Ed Hoornik. DI. 5. Red. K. Lekkerkerker. Amsterdam: Meulenhoff. p. 118-125.)

HOORNIK, E. 1978b. Tussen hemel en aarde: Martinus Nijhoff. (In Hoornik, E. Kritisch proza: verzameld werk van Ed Hoornik. DI. 5. Red. K. Lekkerkerker. Amsterdam: Meulenhoff. p. 142-152.)

HOORNIK, E. 1978c. Forum voorbij. (In Hoornik, E. Kritisch proza: verzameld werk van Ed Hoornik. DI. 5. Red. K. Lekkerkerker. Amsterdam: Meulenhoff. p. 99-107.) 
JAKOBSON, R. 1977. Linguïstiek en poëtica. (In Bronzwaer, W.J.M., Fokkema, D.W. \& Ibsch, E., reds. Tekstboek algemene literatuurwetenschap: moderne ontwikkelingen in de literatuurwetenschap geïllustreerd in een bloemlezing uit Nederlandse en buitenlandse publikaties. Baarn: Ambo. p. 96-106.)

KLOOS, W. 2003. Inleiding. DI. 2. (In Perk, J. Gedichten. Met voorrede van C. Vosmaer en inleiding van Willem Kloos. Bezorgd door Fabian R.W. Stolk. 2e dr. Amsterdam: Bakker. p. 31-40.)

LOONTJENS, J. 2005. Moeder is als een roos: taal en werkelijkheid bij Esther Jansma. http://www.jannahloontjens.nl/result_essay.asp?ld=38 Datum van gebruik: 18 Mei 2009.

LUCAS, E.P.A. 1993. Aanrecht, kraan, servies: "ode" van Gerrit Achterberg, de moderne poëzie, en de radio van 9 februari 1940. Achterbergkroniek, 12(1):41-54.

MERCHANT, P. 1979. The epic. London: Methuen. (The Critical Idiom, 17.)

MIDDELDORP, A. 1985. Grace More en Engel zijn nu samen as: over Criterium. (In Middeldorp, A. De wereld van Gerrit Achterberg. Amsterdam: De Arbeiderspers. p. 54-65.)

MOOIJ, J.J.A. 1995. Lyrische poëzie, verhalende poëzie, en verhalende lyriek. Forum der letteren, 36:316-318.

NIJHOFF, M. 1955. The ferry. Vertaling van zijn gedicht "Het veer" door Henriëtte Schuurbeque Boeye. Maatstaf, 3(6):542-544.

NIJHOFF, M. 1990. Verzamelde gedichten. Tekstverzorging W.J. van den Akker en G.J. Dorleijn. Amsterdam: Bakker.

NIJHOFF, M. 1993. Gedichten: historisch-kritische uitgave. Verzorgd door W.J. van den Akker \& G.J. Dorleijn. 3 delen. Assen: Van Gorcum.

PERLOFF, M. 1996. The dance of the intellect: studies in the poetry of the pound tradition. Cambridge: Cambridge University Press.

RIMMON-KENAN, S. 1996. Narrative fiction: contemporary poetics. London: Routledge.

ROBERTS, A. 1999. Romantic and Victorian long poems: a guide. Aldershot: Ashgate.

ROSS, L. 1986. De jaren dertig. (In Van Bork, G.J. \& Laan, N., reds. Twee eeuwen literatuurgeschiedenis: poëticale opvattingen in de Nederlandse literatuur. Groningen: Wolters-Noordhoff. p. 208-229.)

SCHOLTZ, M.G. 1984. Die digter as leser. (In Viljoen, H., red. In teen die groot vergeet: ' $n$ bundel opstelle opgedra aan T.T. Cloete by geleentheid van sy sestigste verjaardag op 31 Mei 1984. Potchefstroom: PU vir CHO. p. 108116.)

SÖTEMANN, A.L. 1991. Martinus Nijhoff, "Het uur U". Lexicon van literaire werken, 3:1-14, Aug.

T'SJOEN, Y. 2005. Het werd, het was, het is gedaan: nagelaten gedichten van M. Vasalis. (In T'Sjoen, Y. De gouddelver: over het lezen van poëzie. Tielt: Lannoo-Atlas. p. 224-226.)

VAN BOVEN, E. \& DORLEIJN, G. 1999. Literair mechaniek: inleiding tot de analyse van verhalen en gedichten. Bussum: Coutinho.

VAN DEN AKKER, W. 1989. Martinus Nijhoff: "Nieuwe gedichten". Lexicon van literaire werken, 1:1-11, Jan.

VAN DEN AKKER, W. 1994. Dichter in het grensgebied: over de poëzie van M. Nijhoff in de jaren dertig. Amsterdam: Bakker. 
VAN STRAATEN, F. 2009. Populaire Carol Ann Duffy als eerste vrouw benoemd tot Poet Laureate van het Verenigd Koninkrijk: verhalend dichteres van toegankelijke poëzie. NRC-Handelsblad: 7, 2 Mei.

VERWEY, A. 1885-1886. Het sonnet en de sonnetten van Shakespeare. De Nieuwe gids, 1(1):67-96.

VESTDIJK, S. 1971. Verzamelde gedichten. 3 delen. Red. door M. Hartkamp. Amsterdam: Athenaeum-Polak \& Van Gennep.

VESTDIJK, S. 1975. De glanzende kiemcel. 5e dr. Amsterdam: AthenaeumPolak \& Van Gennep.

WALZER, K. 1998. The ghost of tradition: expansive poetry and postmodernism. Ashland: Story line press.

WEVERS, A. 2009. Bittergarnituur. Amsterdam: Contact.

\section{Kernbegrippen:}

classificatie

context

epische poëzie

interpretatie

lyrische poëzie

moderne poëzie

\section{Key concepts:}

classification

context

epic poetry

interpretation

lyrical poetry

modern poetry 